\title{
Customers' perception of current CRM practices at SBI: A case study of State Bank of India, Patna District, Bihar
}

\author{
Jasmine Kaur \\ Research Scholar, Dept. of Applied Economics \& Commerce, Patna University, Patna, Bihar, India
}

*Corresponding Author:

Email: reach.kjasmine@gmail.com

\begin{abstract}
In the current era of economic revolution such as demonetisation and digitization banks are considered to be playing significant role. To sustain in this challenging environment, it is crucial that banks maintain good reputation with their customers. The survival of service organisations is imaginable only if they follow strong CRM (Customer Relationship Management) practices. CRM consists of number of variables that can be studied to understand customers' perception of service quality of these organisations. Banks are also such organisations that entirely subsist on their relationship with their customers. Therefore, it is extremely essential to understand if banks are following worthy CRM practices and whether customers are satiated with these practices or not. It has been observed that certain issues are emerging in the market that may impact the reputation of SBI in Patna. The key reason for these issues is the intense competition in the market between public and private sector banks. Customers are known to be always right and they can effortlessly switch to different banks on account of any negative experience if they come across. In addition to this, it has been identified that private banks are somehow able to attract customers due to their constant run to improve their services and relationships with the customers to survive in the tough market. This factor seems to be lacking in the case of public sector banks such as SBI. In the light of this scenario, a research has been conducted to find out the satisfaction level of customers of SBI with its services. The research provides deep insight into the problems that customers are currently experiencing and suggestions have been provided that may provide solution to the emerging issues in the bank.
\end{abstract}

Keywords: Customer relationship management, Customer satisfaction, Service quality.

\section{Introduction}

Economic revolution is essential to be brought in every sector and this revolution is not without challenges that these sectors are facing. In view of this revolution, banks are also incorporating necessary changes into their existing systems more importantly their CRM practices. It is vital to maintain good customer base in the era of intense competition else this revolution may hit banks hard.

Customers have numerous options available with them as private banks are entering into the markets which are further posing challenges for public sector banks. Due to this reason customers' expectations are also going high and they are expecting to have much better experience and service quality with their bank. Globalisation of businesses has changed the focus from being product oriented to being customer oriented. Providing excellent customer service is a tough challenge for every organisation that especially deals directly with customers on day to day basis.

When customers are inquired about their expectation from their bank, the first thing they think of is effective customer relationship. This relationship consists of different variables such as communication skills of employees of the bank, their knowledge of work, dealing behaviour, politeness etc. that have countless impact on customers. It has been observed that customers do compare public and private sector banks on the basis of the service quality given to them. Hence, it has been identified that even though SBI being a public sector bank has a large customer base, however it is facing several challenges to maintain good reputation with its customers. This takes place on account of number of issues that customers are complaining about the bank. If bank takes strong initiatives to resolve these issues then SBI can become a threat for other public as well as private sector banks.

Servqual model has been used to accomplish objectives of this research work as this model captures consumer expectation and perception of the service quality. There are five dimensions that this model takes into consideration and they are recognised to be representative of service quality. These dimensions are immensely supportive in collecting enough data for the research being done.

\section{Literature Review}

Customers are known to be the best judge when it comes to service quality. Their judgement is based upon several factors and some of these factors (Responsiveness, Assurance, Tangibles, Empathy and Reliability) have been identified by Parsuraman, Berry and Zeithmal which are taken into consideration for conducting the research work of this paper. Their model is popularly known as Servqual model. They believe that ample amount of information regarding service quality of organisations can be gathered based upon these factors (Nargundkar, 2009). Servqual surveys are conducted by the organisations to understand the quality of their relationship with their customers. These surveys are known as relationship surveys which assist banks in analysing their relationship strengths and 
weaknesses. These surveys are also worthwhile in making comparison with competitors (Zeithaml, Bitner, Gremler, \& Pandit, 2011). CRM in banking sector is essential for the survival of the banks, however it is felt that it is still at the evolutionary stage. Banks must take ideas from the customers to enrich their services (Putney \& Puney, 2013). CRM is known to be a process that increases customer satisfaction. In today's competitive business environment if any competitor wants to enter into the market, then it has to focus on satisfying customers. This represents successful implementation of CRM (Shaon \& S. M., 2015). Banking sector is a customer-oriented sector and therefore, research is needed in this sector to analyse customers' needs and attitude in order to build long term relationship with them (Renuga \& Durga, 2016).

The review of Literature has helped in developing conceptual framework of the study.

\section{Objectives of the Study}

Following objectives have been set which are achieved with the help of this research:
1. To comprehend if customers are satisfied with the current CRM practices of SBI in Patna

2. To understand if the bank needs to incorporate essential changes into current CRM practices that can enhance the reputation of the bank.

\section{Research Methodology}

The research for this study is empirical as data has been collected to understand customers' point of view about the CRM practices of SBI. Observations were made to come to conclusion. This data has assisted in framing important suggestions for the banks.

Sample size for research work is 134 customers of SBI. 150 questionnaires were distributed out of which 134 were appropriately filled.

Variables tested for conducting research have been taken from the service model developed by Parsuraman. The model suggests to understand service quality of organisations on the basis of the five factors mentioned below in the diagram. Each factor carries two questions for customers. The input of customers have provided with ample data to perform data analysis and come to conclusion.

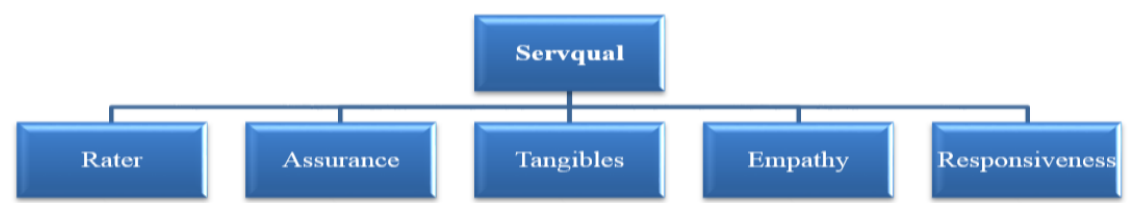

\section{Data Analysis and Results}

Primary sources have been used to collect data for analysing the results. These sources are questionnaires, discussions and interview of the customers which have provided with satisfactory data to come to certain conclusion. The data has been profoundly analysed to understand the customers' perception about the current CRM practices of the bank. The data collected around five dimensions of Servqual model has been diagrammatically represented below.

\section{Reliability}

Q1 - Can you rely on the Employees of the Bank for getting timely services?

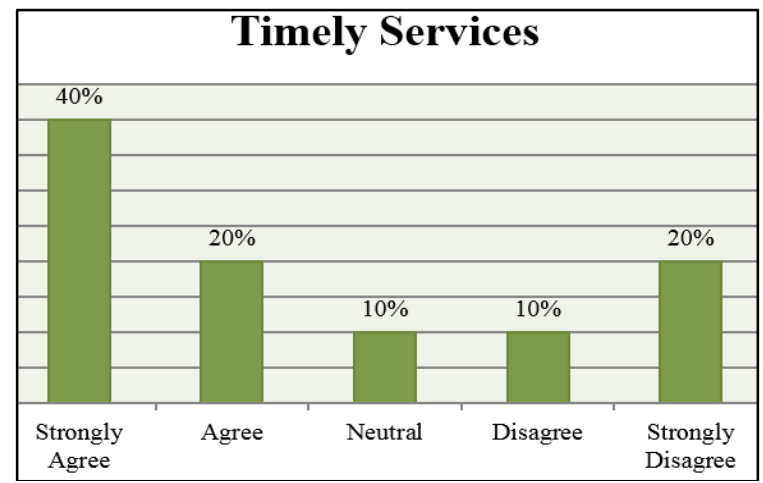

Q2 - Do you trust the information provided by the employees to their customers?

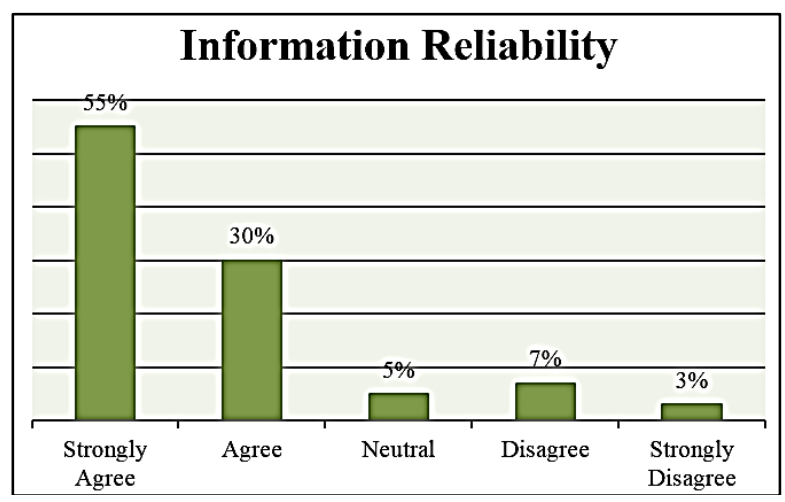

Fig. 2

\section{Assurance}

Q3 - How Polite are the employees of the bank

Fig. 1 


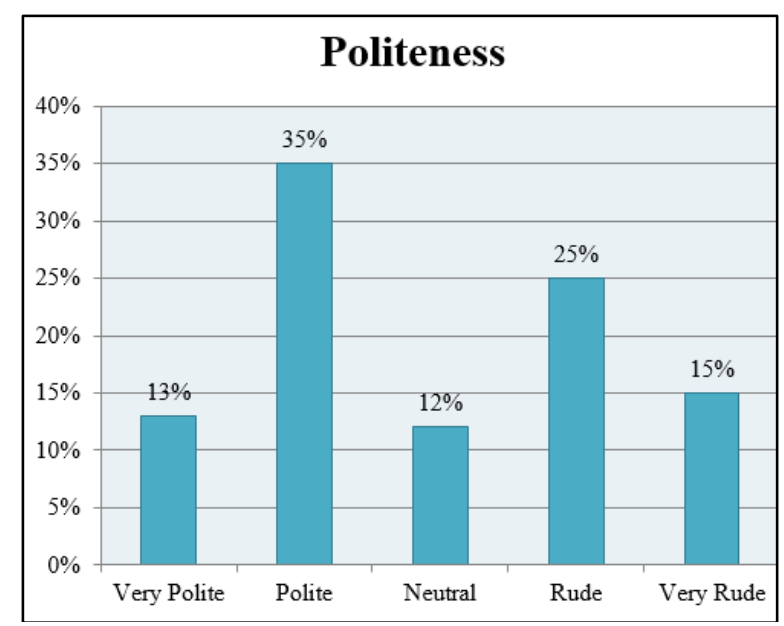

Fig. 3

Q4 - Do you feel that employees are trustworthy in terms of providing information about the products and services?

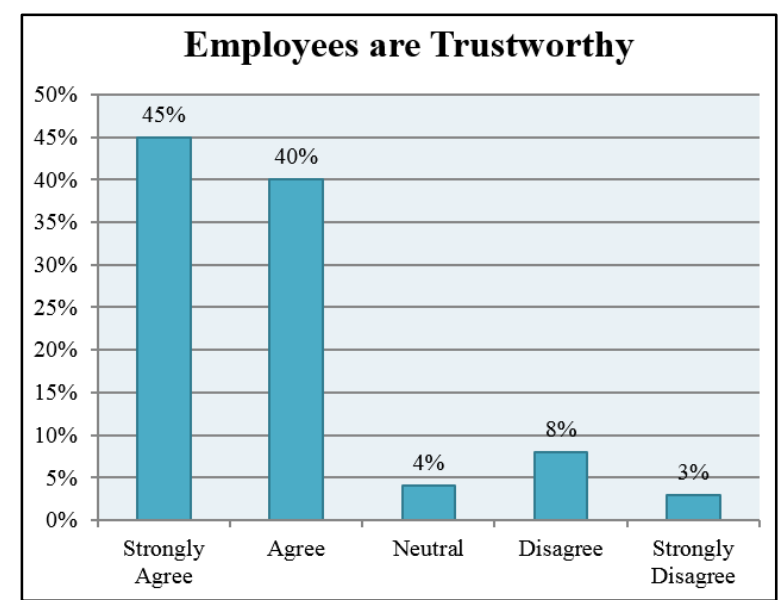

Fig. 4

\section{Tangibles}

Q5 - Are equipment installed in the bank up to date?

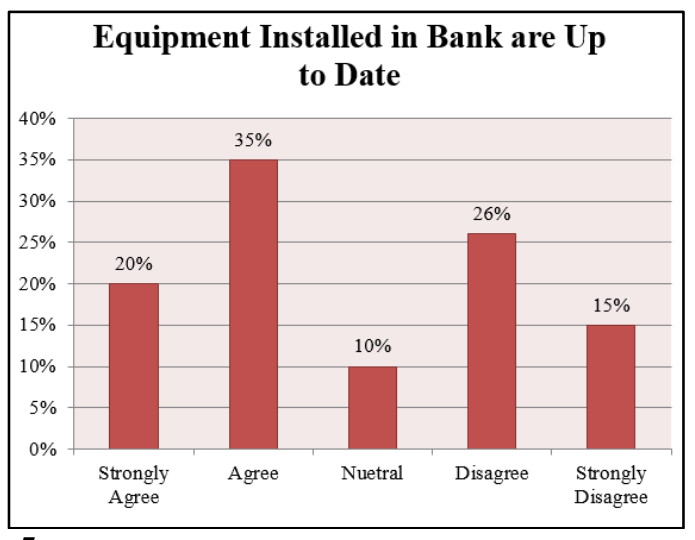

Fig. 5
Q6 - Are equipment or facilities for customers used by the bank visually appealing?

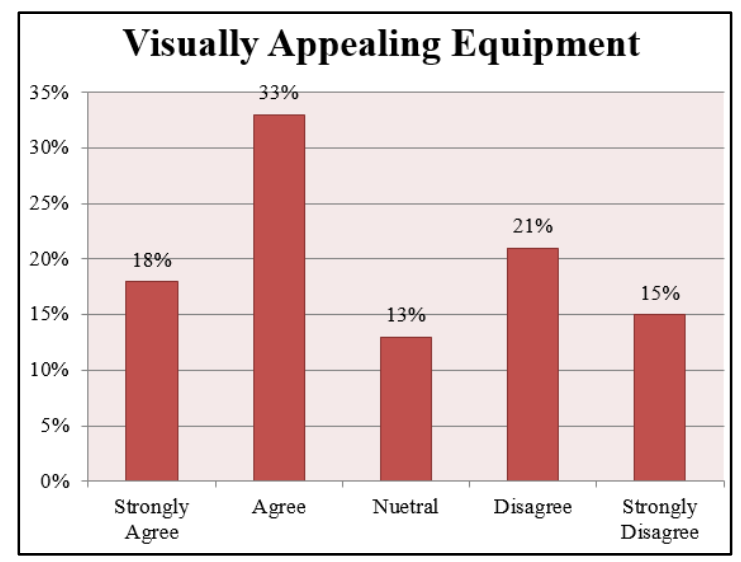

Fig. 6

\section{Empathy}

Q7 - Do you feel that employees understand customers' needs appropriately?

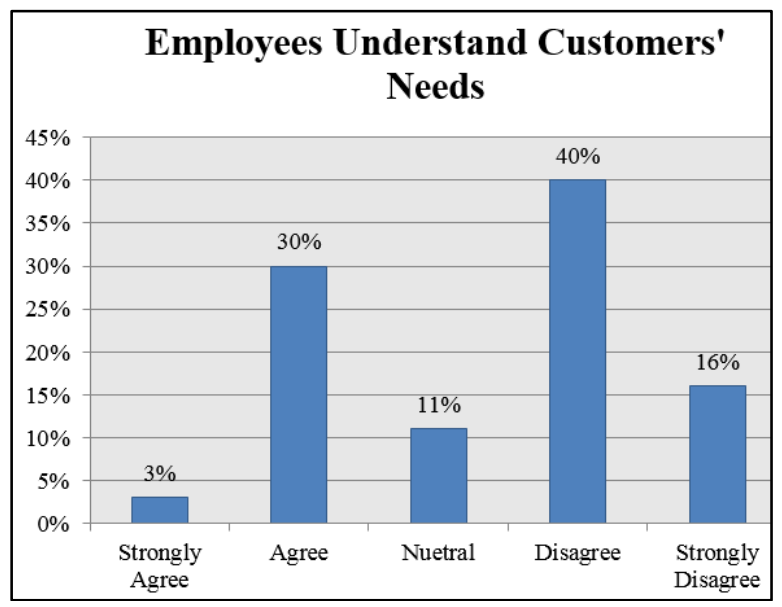

Fig. 7

Q8 - Have you ever received individualized attention from the employees of the bank for resolving any issue?

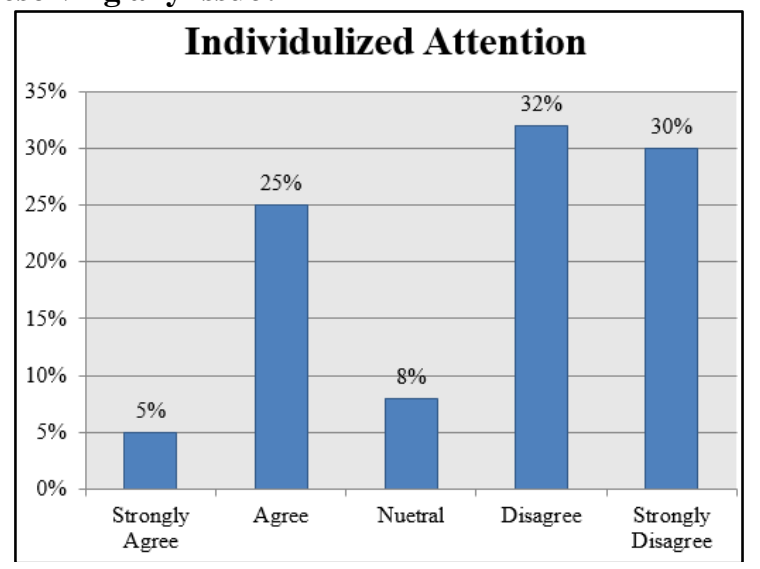

Fig. 8 


\section{Responsiveness \\ Q9 - Do you believe that employees are willing to help for any query or issue?}

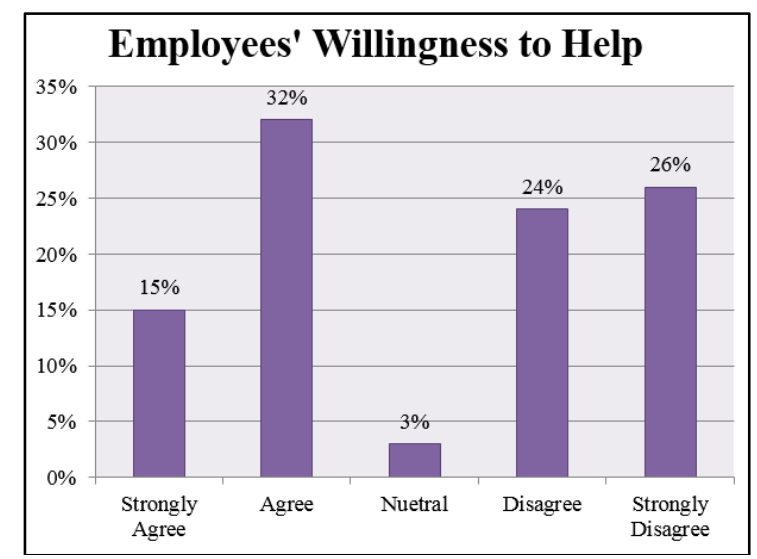

Fig. 9

Q-10 Do you feel that customers are timely informed for any new service that bank introduces?

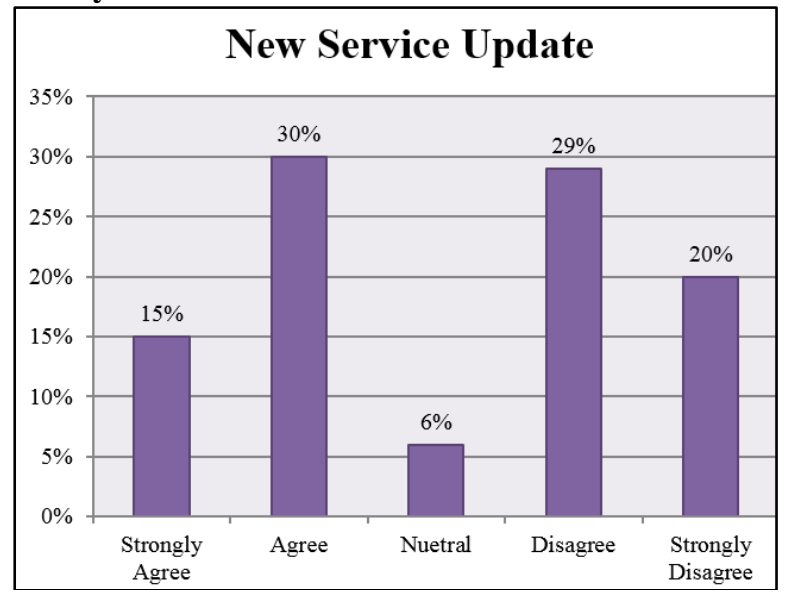

Fig. 10

\section{Findings}

1. The data collected with regards to understanding customers' needs by employees of SBI represents that $33 \%$ of the customers agree that their needs are understood by the employees of the bank whereas $56 \%$ of the customers are of the negative view. This shows that bank needs to work hard on this factor. If customers feel that their needs are not appropriately understood by the employees of the bank then it is going to have harmful effect on the reputation of SBI.

2. It has been identified with the help of questionnaire that only $30 \%$ of the customers agree that they receive individualized attention for resolving any issue. On the other hand $62 \%$ of the customers completely disagree of ever receiving personal attention for getting resolution of their problems. The gap is quite high and may pose serious challenges for banks to survive in the intense competition prevailing in the economy.
3. Employees' willingness to help customers is also displaying negative response for this research work. $47 \%$ of the customers feel that employees are helpful. However, $50 \%$ of the customers do not feel this way. Even though the gap is not quite high but it can certainly hurt the image of the bank while being compared with other banks. A small percentage of negative response can impact banks in a big way.

4. Similarly, $45 \%$ of the customers agree that they are timely informed whenever bank introduces any new service. On the other hand majority of the customers (49\%) say that they are never informed about the introduction of new service. The reason is that customers who do not use mobile banking or net banking do not receive any notification of such services.

\section{Suggestions}

Better Understanding of Customers' Needs: The study conducted during the research work suggests that employees should pay more attention to understand the need of their customers. This would improve the satisfaction level of customers.

Individualised Attention: This factor would enormously improve the image of bank. Those customers who have big issues are looking to receive individualised attention, so that they can be assured to fast and appropriate resolution of their problems. Bank should start emphasising on this dimension of CRM in order to change the perception of its customers.

Employees' Willingness to Help Customers: The research has come up with a valuable suggestion that employees should change their attitude towards helping customers. It has been identified that customers sometimes have to run from one counter to another in the bank in order to get to the right person. Such circumstances are causing dissatisfaction among customers. Therefore, bank should implement this suggestion to eliminate the negative feelings of customers that may have damaging impact on SBI.

Timely Information of New Services to all the Customers: It was found out while collecting data that those customers who do not use Mobile banking or Net banking do not receive timely information about the introduction of new services by the bank. Hence, they remain oblivious of the benefits that their bank is offering to them. So, it is suggested that bank should come with a different way to inform those customers who are not using these services.

\section{Limitations of the Study}

1. The sample size used for the research work may not be sufficient.

2. The research is based in Patna only and other states of the country can be considered for data collection to attain better results. 


\section{Conclusion}

After the analysis performed for this research work, it is understood that CRM is the backbone of the banking industry. Its reputation can be negatively impacted if attention is not paid to develop strong CRM in the banks. Each and every bank is following practices of CRM to face challenges of the rivalry. However, it has been observed that public sector banks are somehow lacking in building strong CRM with their customers and private banks are focusing much more seriously on this. During data analysis, it has been identified that customers are highly satisfied with SBI in Patna, however they are still looking for some important factors to be improved in the bank which would further enhance their satisfaction level. They are looking for some more personalized treatment and employees help in making situations easier for customers. Once bank works upon these lacking factors, it would be able to have long term, contented and profitable business in the market.

\section{References}

1. A, H. O., Osibanjo, O., \& Ojo, S. I. (2014). Effectiveness of Training and Development On Employees' Performance and Organisation's competitiveness In the Nigerial Banking Industry. Nigeria.

2. Das, S. K. Customer relationship management in banking sector: a comparative study of SBI and other nationalised commercial banks in India. $A$

Journal of Economics and Management. 2012;1(6).

3. Ferrazzi, K. (2015, July 31). 7 Ways to Improve

Employee Development Programs. Retrieved March 16, 2017, from hbr.org: https://hbr.org/2015/07/7-ways-toimprove-employee-development-programs

4. Gupta, C. (2013). Human Resource Mangement. New Delhi, Dellhi, India: Sultan Chand \& Sons.
5. Menon, V. S. (2013, May 17). Customer Service and its Impact in Retail Banking. Retrieved April 19, 2017, from vijaymenon2000.wordpress.com: https://vijaymenon2000.wordpress.com/2013/05/17/custo mer-service-and-its-impact-in-retail-banking/

6. Nargundkar, R. (2009). Services Marketing (2nd ed.). New Delhi: Tata McGraw-Hill Publishing Company Limited.

7. Padi, M. G. (2012, September). An Assessment of the Effect of Staff Training on Customer Service Delivery (A Case Study At Barclays Bank Ghana Limited).

8. Pawar, P. (2016, September 1). Importance of Learning \& Development in Banking. Retrieved April 19, 2017, from bq.training: https://bq.training/blog/importance-oflearning-development-in-banking/

9. Putney, A., \& Puney, M. (2013). Importance of Customer Relationship Management (CRM) in The Banking Sector: An Indian Perspective. International Journal of Management \& Business Studies. 2013;3(2).

10. Rani, K., \& Garg, D. A Study on Training and Development in Public Sector Banks. International Journal of Management and Social Sciences Research (IJMSSR). 2014;3(1).

11. Renuga, D. V., \& Durga, D. Customer Relationship Management in Banking Sector. International Journal of Engineering Science and Computing. 2016;6 (8).

12. Shainesh, G., \& Sheth, J. N. (2010). Customer Relationship Management: A Strategic perspective. Chennai.

13. Shaon, K. I., \& S. M., R. H. A Theoratical Review of CRM Effects on Cusstomer Satisfaction and Loyality. PRAGUE ECONOMIC PAPERS. 2015;4(1).

14. Sherlekar, S., \& Krishnamoorthy, R. (2015). Marketing Management. Himalaya Publishing House.

15. Zeithaml, V. A., Bitner, M. J., Gremler, D. D., \& Pandit, A. (2011). Services Marketing (5th ed.). New Delhi: Tatal McGraw-Hill. 